\title{
Proceedings of the
}

\section{CAMBRIDGE PHILOSOPHICAL SOCIETY}

\author{
VOLUME 52
}

PART 3

\section{CAMBRIDGE UNIVERSITY PRESS} LONDON: BENTLEY HOUSE, N.W.1 NEW YORK: 32 EAST 57TH STREET, 22

Price Thirty Shillings Net (U.S.A. \$5.00) Subscription price per volume $£ 5$ net post free (\$16.75 in U.S.A.) 


\section{CAMBRIDGE PHILOSOPHICAL SOCIETY \\ FOUNDED 1819; ROYAL CHARTER 1832}

\section{Session 1955-1956}

\section{President: F. J. W. ROUGHTON}

Vice-Presidents: E. C. BATE-SMITH, H. J. EMELEUS, F. G. YOUNG

Treasurer: M. V. WILKES

Secretaries: (Mathematical) H. G. EGGLESTON

(Physical) T. E. FABER

(Biological) S. SMITH

The publications of the Society consist of the Proceedings and of the Biological Reviews. The publication of Transactions was suspended at the end of Volume XXII.

Orders should be sent to: The Manager, Cambridge University Press, Bentley House, 200 Euston Road, London, N.W.1. Enquiries from the U.S.A. should be addressed to the Cambridge University Press, American Branch, 32 East 57th Street, New York 22, U.S.A.

For the purchase of early parts of the Transactions and Proceedings application should be made to the Secretaries. The current price for these early parts is the original selling price, plus $50 \%$.

Fellows and Associates of the Society are particularly requested to inform the Secretaries of any change of postal address, and to send their subscriptions to the Treasurer, CAMBRIDGE Philosophical Society, Free School Lane, Cambridge.

\section{PROCEEDINGS of the CAMBRIDGE PHILOSOPHICAL SOCIETY}
F. J. ANSCOMBE
edited by

\begin{tabular}{lll} 
F. J. ANSCOMBE & H. G. EGGLESTON & H. P. F. SWINNERTON-DYER \\
& \multicolumn{1}{c}{ in consultation with } \\
$\begin{array}{lll}\text { T. E. FABER } & \text { D. R. HARTREE } & \text { C. B. HASELGROVE } \\
\text { D. G. KENDALL } & \text { F. SMITHIES } & \text { F. URSELL } \\
& \text { D. H. WILKINSON } & \end{array}$
\end{tabular}

1. Four parts of the Proceedings are issued each year.

2. Communications for the Proceedings should be sent to The Librarian, Cambridge Philosophical Society, Free School Lane, Cambridge. Papers by Fellows and Associates of the Society should be communicated directly by the author. Other papers must be communicated by a Fellow, who in doing so should give his opinion on the suitability of the paper for publication.

3. Papers occupying more than twenty pages of print can only very rarely be accepted.

4. It is recommended that each paper be prefaced by a short abstract. Copies of a Guide for the Preparation of Synopses, prepared by the Abstracting Services Consultative Committee and issued by the Royal Society, may be obtained from the Librarian.

5. Drawings for illustrations and diagrams should be on a large scale and on smooth white Bristol board in Indian ink.

6. References should be listed at the end of each paper, in alphabetical order of authors. World List abbreviations for titles of journals should be used.

7. Authors are particularly requested to prepare their manuscripts in a form suitable for printing, with adequate margins. A pamphlet on the preparation of papers may be obtained from the Librarian. If a large number of corrections are required in the proofs, the Council reserves the right to make a charge towards the cost.

8. Authors may receive, on request, fifty offprints of a paper in the Proceedings without charge. 


\section{Expanding Universes}

\section{E. SCHRÖDINGER}

Professor Schrödinger explains some of the puzzling properties of expanding flat and spherically closed world-models. His exposition requires knowledge of the calculus and of analytic geometry, but does not presuppose acquaintance with Einstein's theory of gravitation.

17s. 6d. net

\section{The Structure of Turbulent Shear Flow}

\section{A. A. TOWNSEND}

The first book to attempt a systematic and comprehensive discussion of all kinds of turbulent motion, and the first to provide a reliable analysis of the processes which occur.

\section{Automation: Friend or Foe?}

\section{R. H. MACMILLAN}

An account of the technical problems and the human consequences of Automation. The author traces the history of automatic control devices, considers the principles at the root of all automation systems, and discusses economic and social factors.

8s. 6d. net

\section{Integral Functions}

\section{L. CARTWRIGHT}

This tract clarifies parts of the theory of integral functions, discussing in detail the behaviour of a function of finite order in an angle, and applying the results to the theory of the Phragmén-Lindelöf function and other branches of Analysis. No. 44 of the Cambridge Mathematical Tracts.

I8s. net

CAMBRIDGE UNIVERSITY PRESS

BENTLEY HOUSE, 200 EUSTON ROAD, LONDON, N.W. 1 


\section{ROYAL STATISTICAL SOCIETY}

The Journal of the Royal Statistical Society is published in two series: Series A (General), four issues a year, 15s. each part, annual subscription £3. $1 s$. post free; SERIES B (METHODOLOGICAL), two issues a year, 22s. $6 d$. each part, annual subscription $45 s$. $6 d$. post free.

\section{Contents of Series B (Methodological), Vol. 17, Part 2, 1955}

Some Statistical Methods Connected with Series of Events. By D. R. Cox (with Discussion).

Symposium on Linear Programming:

An Outline of Linear Programming. By S. VaJdA.

On Minimizing a Convex Function Subject to Linear Inequalities. By E. M. L. Beale.

A Contribution to the 'Travelling-Salesman' Problem. By G. MortoN and A. H. LAND (with Discussion).

Statistical Concepts in their Relation to Reality. By E. S. PEArson.

The Comparison of Means of Sets of Observations from Sections of Independent Stochastic Series. By G. H. JowETT.

A Note on the Periodogram of the Beveridge Wheat Price Index. By J. C. GOWER.

Some Distribution and Moment Formulae for the Markov Chain. By P. WhitTLE.

Some Applications of Zero-one Processes. By Z. A. LoMnICKI and S. K. ZAREMBA.

Waiting Time in Bulk Service Queues. By F. Downton.

A Note on Equalizing the Mean Waiting Times of Successive Customers in a Finite Queue. By Norman T. J. BaIley.

On the Weighted Combination of Significance Tests. By I. J. GooD.

A Significance Test for the Difference in Efficiency between Two Predictors. By M. J. R. Healy.

A Unified Theory of Sampling from Finite Populations. By V. P. Godambe.

Obtainable through any bookseller or direct from:

ROYAL STATISTICAL SOCIETY

21 BENTINCK STREET, LONDON, W. 1

(ii) 